\title{
NOWY PARADYGMAT DYDAKTYCZNY: KOMPONENT KREATYWNY
}

\author{
NATALLIA NiZHNEVA, JAN ZANIEWSKI, \\ NADZIEJA NIZHNEVA- KSENOFONTAVA
}

Obecnie coraz częściej obserwuje się dynamiczny, konkretnie-historyczny charakter paradygmatów kształcenia, które, jak podkreśla się w badaniach ostatnich lat, w ten lub inny sposób odzwierciedlają obraz otaczającej rzeczywistości. Z pełnym przekonaniem możemy mówić o wielopostaciowości podmiotów działalności kształcenia, celów, zadań, funkcji kształcenia, które tworzą jego poliparadygmatyczność.

\section{Paradygmat kształcenia. Aktualne podejścia}

Istnieje kilka podejść do określenia paradygmatu kształcenia, rozpatrywanych jako: podejście dominujące w wyborze treści, form organizacji kształcenia, sposobu nauczania i wychowania; wyjściowy schemat pojęciowy, model ujęcia i ich rozwiązania w dziedzinie kształcenia;

wyjściowa bazowa matryca kształcenia, zawierająca w sobie podstawy, środki nauczania i wychowania, ideał uczącego się w jego jakościowy całokształt wiedzy, nawyków, myślenia i umiejętności, zawierających fundamentalne wyobrażenia o świecie, społeczeństwie i człowieku, wartości, ideały i normy stosunku do świata i współżycia społecznego ${ }^{1}$.

Rozpatrywany jest także humanitarny paradygmat kształcący, w centrum, którego zawarty jest przyswajający gotową wiedzę człowiek, poznający swoją istoto-

\footnotetext{
${ }^{1}$ П.А. Денисенко. Парадигму образования в социокультурном пространстве современного российского общества. Москва, ВУ, 2009, с. 103.
} 
wość. Przy tym współpraca, wspólna twórczość, dialog, wymiana poglądów stają się podstawowymi zasadami, na których budowane są wspólne działania i relacje pomiędzy uczestnikami procesu dydaktycznego.

Zmiana paradygmatu uwarunkowana jest socjokulturowymi transformacjami, wywołanymi postindustrialną, kulturą informacyjną, która charakteryzuje się ogromną ilością informacji. ${ }^{2}$ To naturalnie wymaga od uczących się odpowiednich umiejętności, niezbędnych do zdobycia wiedzy i dla twórczego ich wykorzystania. M. Dunina zauważa, że nauczać to - z pasją poznawać, tolerancyjnie komunikować się, twórczo pracować i godnie żyć - w tym zawarty jest sens i przeznaczenie wykształcenia. W tym jego jakość, którą dość prosto można prześledzić u poszczególnych studentów i wykładowców, a także w społeczeństwie.

Zbudowane na zasadach uniwersalności, integracyjności, humanitaryzmu, komunikatywności i ciągłości kształcenia poprzez metaprzedmiotość, dialogiczność, problemowość, kolejność, uzupełnianie, otwartość, twórczość, samoaktualizację i samowystarczalność studenta i wykładowcy stwarzają niezbędne i wystarczające psychologiczno-pedagogiczne warunki dla wychowania człowieka, umiejącego żyć w jedności przyrodą i społeczeństwem, adaptować się z nim, przyjąć je jako wartości istotne ${ }^{3}$.

Inni autorzy do podstawowych komponentów paradygmatu kształcenia zaliczają: stosunek wykładowcy do studenta i jego pozycji w procesie kształcenia; określenie funkcji kształcących (humanitarnej, kulturotwórczej, funkcji socjalizacji); treści kształcenia (aksjologicznej, kognitywnej, twórczej, osobowościowy kompnent); pedagogicznej i glottodydaktycznej technologii kształcenia.

Szczególnie należy podkreślić fakt, że współczesny stan kształcenia można scharakteryzować $\mathrm{w}$ literaturze naukowej jako poliparadygmatyczny, ponieważ w nim obok wiedzy, jest jednocześnie zawarty kulturologicznie, kompetencyjnie i osobowościowo zorientowany paradygmat kształcenia.

Współczesny paradygmat kształcenia jest precyzyjnie wyrażony i zorientowany na osobowość, która odpowiednio z wymaganiami czasu konkretyzuje się i uzupełnia się szeregiem podejść, w skład których wchodzą takie elementy jak: czynny,

\footnotetext{
${ }^{2}$ Aktualnie sumaryczna objętość wiedzy podwaja się średnio co każde dziesięć lat, w XVIII wieku - co 150 lat. $30 \%$ zdobytej w kształceniu uniwersyteckim wiedzy starzeje się od razu po zakończeniu uczelni, nowatorstwo pracy habilitacyjnej trwa 4 dni. Badacze Uniwersytetu w Kalifornii obliczyli, iż tylko w 2006 r. światowe ośrodki informacji, wydawnictwa i przemysł reklamowy wyprodukowały o 3 mln. razy więcej informacji, niż wszystkie książki, napisane przez całą historię ludzkości. W $2010 \mathrm{r}$. objętość ta powiększyła się 6-krotnie. Badania wskazują, że w XV-XVII wieku dobrze wykształcony europejczyk otrzymywał w ciągu całego swego życia zasób informacji, który dzisiaj odpowiada jednemu numerowi New York Times. Кузина, С. 2011. Мозг врёт! Тайна мозга. Знаем мозг - управлякм собой. Москва, АСТ, Астрель, с. 5.

${ }^{3}$ Дунина, М. Новая образовательная парадигма: проблемы качества образования. // Современные проблемы науки и образования. 2006 № 5, с. 32-34. URL: http://www.science-education. ru/ruarticle/view?id=513 (data inf.: 17.10.2016).
} 
kompetentny, kulturologiczny, międzykulturowy, socjokulturowy, kognitywno-komunikacyjny i inne. Należy podkreślić fakt, iż praktycznie każde z tych podejść rozpatruje w charakterze swoich obiektów takie kategorie jak intelektualny i twórczy rozwój osób nauczanych. Szczególną naszą uwagę, odpowiednio, zwraca problem badania kreatywności.

\section{Kreatywność jako ważny komponent paradygmatu kształcącego}

W związku z zagadnieniem kreatywności jako ważnego komponentu paradygmatu kształcącego, istotnym kierunkiem jest badanie takich zagadnień jak: myślenie, twórczość, poziomy twórczości, kreatywność, które obecnie znajdują się w centrum uwagi badaczy krajowych i zagranicznych, ponieważ właśnie kreatywność jest jednym z kluczowych komponentów współczesnego paradygmatu kształcącego.

Twórczość w literaturze naukowej rozpatrywana jest jako obraz życia człowieka (a nie tylko jako rozwiązywanie konkretnych zadań), a człowiek jako twórca własnego życia. E. Fromm, na przykład, określa twórczość jako umiejętność, która pozwala „dziwić się i poznawać, umiejętność znajdowania decyzji w sytuacjach niestandardowych, tj. ukierunkowanie na odkrycie nowego i zdolność do głębokiego uświadomienia swego doświadczenia"4.

L. Kitajew-Smyk ${ }^{5}$ pisze o trzech poziomach twórczości: kompilacyjnym, projekcyjnym i wewnętrzno-kreatywnym.

Badane są także bariery blokujące twórczość w planie osobowości, przejawiające się w:

- konformizmie - chęci bycia podobnym do innych; strachu przed wypowiadaniem własnego zdania, bycia śmiesznym, zgadzanie się;

- cenzurze zewnętrznej i wewnętrznej - świadomym lub nieświadomym zagłuszaniu nietradycyjnych, niezwykłych myśli w wyniku dominowania w osobowości superego;

- twardości ('rigidności', łac. rigidus - twardy) myślenia - stereotypowość myśli, przyzwyczajenie rozwiązywania typowych zadań standardowym sposobem, co może być wynikiem nauki w szkole;

- impulsywności myśli - chęci znalezienia odpowiedzi natychmiast, podejmowania nieprzemyślanych, nieadekwatnych decyzji, które powstają przy silnej motywacji;

\footnotetext{
${ }^{4}$ Фром, Э. Душа человека. 1992. Москва, с. 119. У. Ильин. Психология творчества, креативности, одаренности. 2009, Санкт-Петербург: Питер, с. 16.

${ }^{5}$ Китаев-Смык. Факторы напряженности твоческого процесса. Вопросы психологии, № 3, c. 69-82. Poziom kompilacyjny związany jest z gromadzeniem, klasyfikacją, rubrykacją, rangą już wcześniej poznanych faktów. Poziom projekcyjny ma miejsce, kiedy tworzą się uogólnione nowe sądy na podstawie zebranej wiedzy. Poziom wewnętrzno-kreatywny związany z olśnieniem, kiedy twórca nieoczekiwanie zauważa coś nowego, nieoczekiwanie dla niego.
} 
- egocentryzmie poznawczym - niezdolności do przejścia od jednego punktu widzenia do innego, zmiany perspektywy poznawczej.

Odnośnie określenia kreatywności, to już w latach 60-ch XX w. pojawiło się 60 określeń kreatywności. Dzielono je na sześć typów $\left.{ }^{6}: 1\right)$ gestaltyczne (niem. Gestalt obraz, forma), 2) innowacyjne, 3) estetyczne, 4) psychoanalityczne, 5) problemowe, 6) określenia, które nie trafiły do żadnego $\mathrm{z}$ w/w typów, w tej liczbie i dosyć mgliste.

Zdaniem M. Chołodowej, kreatywność - to zdolność podjęcia racjonalnego ryzyka, przezwyciężania przeszkód, motywacja wewnętrzna, tolerancyjność dla nieokreśloności, gotowość do przeciwstawiania się poglądom otoczenia ${ }^{7}$. D. Gilford pod pojęciem kreatywności rozumie zdolność tworzenia wielu oryginalnych idei w niestandardowych warunkach działania, jako zdolność twórczego myślenia i tworzenia czegoś nowego w doświadczeniu. Kreatywność przejawia się przy definicji wiedzy, w procesie włączenia informacji do nowych struktur i związków, identyfikacji niepełnej informacji, poszukiwań nowych rozwiązań i ich sprawdzenia, informowania o ich wynikach ${ }^{8}$. Aby kreatywność przerodziła się w twórczość, winna ona być połączona $\mathrm{z}$ wysokim wskaźnikiem inteligencji lub, jak niektórzy twierdzą, inteligencją sukcesu.

W niektórych pracach pojawia się termin „kreatywizm”, który rozumiany jest, jako zdolność do tworzenia. Dość szeroką popularność zyskuje też termin „kompetencja kreatywna", znaczenie którego całkowicie pokrywa się ze znaczeniem kreatywności. Kreatywność rozpatrywana przez psychologów rozumiana jest jako zdolność do tworzenia, jednak nie jako sama twórczość.

Zgodnie ze współczesnymi podejściami, twórczość rozpatrywana jest jako sposób efektywnego samorozwoju i profesjonalno-osobowościowej samorealizacji, a twórcza osobowość - jako osobowość z w pełni konkretnym ukierunkowaniem na twórczość.

W związku z tym, jednym z podstawowych problemów dydaktycznych, stojących przed wykładowcą przy organizacji procesu kształcenia na uczelni, jest na-

\footnotetext{
${ }^{6}$ Taylor, C.W. Various approaches to and definitions of creativity// R. Sternberg (eds.). The nature of creativity. Cambridge. Cambridge University Press. P. 99-126. Typy gestaltyczne, opisujące proces kreatywny, jako rozpad istniejącego gestaltu dla budowy lepszego; typy innowacyjne, zorientowane na ocenę kreatywności według nowości produktu końcowego; typy estetyczne, lub ekspresywne, zorientowane na wyrażenie siebie przez twórcę; typy psychoanalityczne, lub dynamiczne, opisujące kreatywność w terminach we współzależności; typy problemowe; określające kreatywność przez szereg procesów rozwiązywania zadań, do tego typu odnosi się i określenie Golforda kreatywności, jako myślenia dywergentnego.

${ }^{7}$ Холодова, М. Психология интеллекта. Парадоксы исследования. 2002.Санкт-Петербург, Питер.

${ }^{8}$ Torrance, E.P. Guiding creative talent/ E.P. Torrance. - Englewood Cliffs, N. J: Prentice-Hall. 1966. Ильин, Е.П. Психология творчества, креативности, одаренности. 2009. Санкт-Петербург, Питер c. 158 .
} 
uczanie sposobów i nawyków działalności twórczej, które nie układają się w ramy tradycyjnych trzyetapowych modeli, zawierających poznanie, trening i zastosowanie z towarzyszącą im kontrolą.

W piśmiennictwie naukowym opisane są różne modele myślenia kreatywnego. Jeden z pierwszych modeli został zaproponowany w latach 30-ch XX wieku przez G. Wallasa. Składa się on z czterech stadiów: przygotowanie (formułowanie problemu, szukanie informacji, badanie znanych sposobów); inkubacja (dojrzewanie: o ile znane sposoby rozwiązania nie pomogły, zadanie odkłada się, dana osoba przełącza się na inne zajęcia); olśnienie (ang. insight, moment, kiedy powstaje nowa idea); weryfikacja (wszechstronna analiza znalezionego rozwiązania na dopuszczalność i przydatność).

Z kolei model J. Rossmana jest powiększony do siedmiu etapów: określenie potrzeby lub problemu; analiza potrzeby lub problemu; uogólnienie informacji, dostępnej na temat problemu; formułowanie wszystkich możliwych wariantów rozwiązania; krytyczna analiza wariantów, z punktu widzenia ich silnych i słabych stron; okrycie - pojawienie się nowej idei; eksperyment w celu znalezienia optymalnego rozwiązania, końcowy wybór i dopracowanie ${ }^{9}$.

Model śnieżynki (płatka śniegu) D. Perkinsa zawiera sześć cech charakteryzujących kreatywny umysł: obecność potrzeby uporządkowania i znalezienia sensu tego, co powstaje chaotycznie; mobilność umysłowa; wyróżniająca się zdolność rozwiązywania problemów; chęć ryzyka i brak strachu przed porażką; dążenie do otrzymywania uwag krytycznych i zdolność o zwrócenia się o pomoc do kolegów $\mathrm{z}$ autorytetem, nie doświadczając przy tym uczucia wstydu; motywacja wewnętrzna, oparta na twardym przekonaniu w swych poglądach, opartych na silnej wierze w to, że one działają ${ }^{10}$.

\section{Przygotowanie twórczo myślących specjalistów: warunki pedagogiczne}

Rozwiązanie problemu przygotowania myślących specjalistów nie jest możliwe bez twórczości pedagogicznej, rozpatrywanej, jako poszukiwanie i znajdowanie nowego w sferze działalności pedagogicznej. Pierwszy stopień tej twórczości - odkrycie nowego dla siebie, znalezienia niestandardowych sposobów rozwiązania zadań pedagogicznych. Te sposoby, pomimo, że są już znane i opisane, nie były jednak wykorzystywane przez pedagogów. Drugi stopien - odkrycie nowego nie tylko dla siebie, lecz i dla innych, tj. nowatorstwo.

\footnotetext{
${ }^{9}$ Рон Алан Дж. Креативное мышление/ Алан Дж. Роу; пер. с англ. В. Островской. 2007. Москваб НТ Пресс, 176 с.

${ }^{10}$ Torrance, E.P. Guiding creative talent/E.P. Tarrance. - Tnglewood Cliffs, 1966. N.J. Prentice Hall.
} 
Szczególnym rodzajem twórczości pedagogicznej jest improwizacja - znajdowanie nieoczekiwanego rozwiązania pedagogicznego i jego zastosowanie. Opisywane są cztery etapy procesu improwizacji: 1) olśnienie pedagogiczne; 2) nagłe uzmysłowienie intuicyjnie powstałej idei pedagogicznej i momentalny wybór drogi jej realizacji; 3) publiczne zastosowanie tej idei i 4) uświadomienie, tj. momentalna analiza procesu realizacji idei pedagogicznej ${ }^{11}$.

Określenie optymalnych pedagogicznych warunków przygotowania twórczo myślących specjalistów, władających profesjonalną kreatywnością, staje się wybitnie ważnym zagadnieniem.

Aktualność tego zagadnienia uwarunkowana szeregiem czynników obiektywnych. Po pierwsze, obserwuje się sprzeczność pomiędzy wzrastającym zapotrzebowaniem na specjalistów z rozwiniętym twórczym myśleniem a niedostatecznym poziomem samodzielnej aktywności studentów w rozwoju profesjonalnie znaczących jakości, które zabezpiecza się przez proces kształcący.

Po drugie, widoczne jest ukształtowanie sprzeczności między zapotrzebowaniem na pedagogów-nowatorów z jednej strony a jakością przygotowania ogólnopedagogicznego, które w dostatecznej mierze nie sprzyja realizacji możliwości jego twórczej samorealizacji, z drugiej strony.

Odpowiednio cel badań $w$ tej dziedzinie określany jest jako opracowanie pedagogicznych warunków doskonalenia twórczego rozwoju i wyrażenia swojej osobowości w procesie działalności dydaktycznej, co jest ważnym środkiem wiodącym do przygotowania specjalisty do podjęcia działalności innowacyjnej.

W.P. Michajłowa i współautorzy ${ }^{12}$ na przykładzie działalności dydaktycznej próbowali wydzielić poziomy twórczego rozwoju osobowości, treść których szerzej cytuje w swych pracach E. Ilin ${ }^{13}$.

Niższy poziom przejawia się w zdolności analizie sytuacji przedmiotowej w celu jej przekształcenia; w analizie tekstów naukowych i literackich, w uświadomieniu problemów życiowych i własnego doświadczenia dla rozwiązania praktycznych zadań. Neologizmami tego poziomu twórczego rozwoju są umiejętności na nowo, niestandardowe spojrzenie na sytuację, szeroki zakres działań przy realizacji zadań problemowych, tj. alternatywność myślenia.

Średni poziom twórczego rozwoju osobowości przejawia się w refleksji odnośnie tego, co <ja mogę $>$ i czego <ja chcę>, w pojęciu determinant osobistego rozwoju, w umiejętności stawiania celów i zadań odnośnie samokształcenia i samodoskonalenia.

${ }^{11}$ Ильин, Е. Психология творчества, креативности, одаренности/ 2009. Санкт-Петербург, Питер с.21.

${ }^{12}$ Михайлова, В., Корытченкова, Н., і И. Львова, Концепция уровней творческого развития личности.//Ананьевские чтения. Тезисы научнопрактической конференции. 2002. Санкт-Петербург, c. 341-342.

${ }^{13}$ Ильин, Е. Психология творчества, креативности, одаренности. 2009. Санкт-Петербург, Питер, с. 22. 
Psychologicznymi neologizmami tego poziomu są adekwatne zobaczenie siebie, umiejętność analizowania swoich działań, przewidywanie ich następstw.

Wyższy poziom twórczego rozwoju daje możliwość efektywnego wpływu na innych ludzi niezauważalnie dla nich samych. Dany poziom rozwoju przejawia się w umiejętności projektowania osobowości drugiego człowieka i przewidywania jego działań, w umiejętności bronienia swego punktu widzenia i uwzględniania poglądu innych. Ludzie tego poziomu są zarówno marzycielami jak i pragmatykami, są samodzielni i niezależni, elastyczni, efektywni i emocjonalnie zrównoważeni.

Kompleks rozwiązywanych zadań dla osiągnięcia wyznaczonego celu zawiera:

- określenie sposobów metodologicznych analizy twórczej aktywności jednostki i ustalenie jej istoty;

- teoretyczno-metodologiczną analizę fenomenu twórczego wyrażenia siebie, jako niezbędnego środka przygotowania specjalisty do działalności innowacyjnej;

- ekspozycję podstawowych charakterystyk procesu kształcenia i uzasadnienie systemu pedagogicznych warunków, sprzyjających twórczemu pokazania siębie i samokształceniu osobowości studenta;

- opracowanie zorientowanej na osobowość technologii formowania u studentów umiejętności i nawyków profesjonalno-twórczego samorozwoju.

Ważną zasadą organizacji procesu dydaktycznego (w szczególności nauki języków obcych), skierowanego na twórczy rozwój osobowości, jest wykorzystanie kreatywnej sytuacji ${ }^{14}$ w charakterze efektywnego sposobu nauczania i niezbędnego warunku kształtowania komunikacyjnej i profesjonalnej koncepcji, rozwoju twórczych i intelektualno-heurystycznych zdolności, zawierających takie komponenty jak: zdolność do generowania idei; fantazja, wyobraźnia; zdolność do wykorzystywania analogii; dostrzegania sprzeczności, problemu; przekazywanie wiedzy, umiejętności; zdolność odrzucenia natrętnej idei; niezależność sądów; krytyczność myślenia; refleksja; bystrość, operatywność pamięci; spostrzegawczość w znajdywaniu problemu; zdolność do redukcji operacji myślowych; giętkość myślenia; pamięć skojarzeniowa; umiejętność oceny przeczytanego tekstu, zdolność łączenia przyjmowanej informacji z już znaną; zdolność do wyobraźni (logicznej, krytycznej, twórczej i in.). Przy określaniu statusu sytuacji kreatywnej wskazanym jest kierować się w/w przesłankami.

\footnotetext{
${ }^{14} \mathrm{~W}$ szerokim sensie tego terminu sytuacja rozpatrywana jest jako: a) złożony kompleks dialektyki powiązanych zewnętrznych warunków komunikacji i wewnętrznych reakcji uczących się, przedstawionych w odpowiedniej lingwistycznej oprawie; b) uniwersalna forma funkcjonowania procesu komunikacji, istniejąca jako integracyjny dynamiczny system socjalno-sytuacyjnych, aktywnych i moralnych współzależnych stosunków, podmiotów komunikacji, odzwierciedlenia w ich świadomości i powstająca na podstawie współdziałania sytuacyjnych pozycji komunikujących się osób; c) forma organizacji procesu nauczania; d) system wzajemnych relacji.
} 
Wyróżniającą cechą sytuacji kreatywnej jest to, że ona jest przeznaczona dla stworzenia realnych sytuacji komunikowania się, w tej liczbie także profesjonalnego, sprzyjających stymulowaniu i rozwojowi twórczej działalności osób nauczanych, nieograniczających ich intelektualnej aktywności. Ma to wyjątkowo ważne znaczenie, ponieważ, jak ustalono, na przykład, sytuacje problemowe nie są adekwatnymi dla badania intelektualnej aktywności (samodzielności poznawczej), gdyż $\mathrm{z}$ jednej strony, zewnętrznie stymulują ją i w tymże czasie ograniczają jej przejawy ramami określonego zadania.

Podstawowymi parametrami sytuacji kreatywnej są: wartość poznawcza; ukierunkowanie przewidujące obecność motywu i celu; strukturalność przedstawiająca sobą zorganizowanie wewnętrzne; sytuacyjność, kontekstowość, systemowość; adekwatność stwarzanych sytuacji dla realnych profesjonalnych potrzeb; informacyjność, tj. wymiana nowych informacji; stymulacja aktywności umysłowej osób nauczanych; zgodność poziomu profesjonalnej i komunikacyjnej kompetencji osób nauczanych; obecność poczucia subiektywnie mniej lub bardziej znacznego deficytu informacji.

W ten sposób, sytuacja kreatywna może być określona jako kompleks warunków zewnętrznych, a także wielorakich form indywidualnego i wspólnego twórczego działania, stwarzających realne sytuacje komunikacji profesjonalnej i pobudzających do aktywnego twórczego działania, sprzyjającego rozwojowi twórczej motywacji, niezbędnej do przygotowania specjalistów zdolnych twórczo rozwiązywać profesjonalne zadania. Niniejsza sytuacja winna być rozpatrywana, jako system współdziałających konkretnych czynników obiektywnego i subiektywnego planu, wciągających osobę do kontaktu słownego, zabezpieczając jego przebieg, informacyjnie i emocjonalnie podtrzymując go i określając zachowanie się osoby (w granicach aktu obcowania) oraz roli mówiącego i słuchającego (kontekst komunikacyjno-mowny) oraz zbiór konkretnych pozajęzykowych czynników informacyjnych, wciągających człowieka do komunikacji językowej i określających jego zachowanie, tak w pozycji mówiącego, jak i słuchającego.

Ważną zasadą stworzenia sytuacji kreatywnych jest zasada planowego utrudnienia, stymulowania i rozwoju twórczego, poznawczego ogniwa działalności myślowej studentów, rozszerzenie spektrum ich możliwości intelektualnych i zdolności twórczych oraz odpowiednio przeważające wykorzystanie w procesie dydaktycznym systemu zadań problemowego, twórczego charakteru (tzw. 'zasada ekwilibrystyki mózgowej').

Przy tworzeniu sytuacji istnieje konieczność opracowania ujednoliconych wymogów do ich klasyfikacji, tj.:

- według źródeł powstawania i sposobów rozwiązania (warunków rozwiązania);

- według charakteru realizowanej działalności poznawczej;

- według stopnia trudności rozwiązania sprzeczności;

- według ich współzależności z praktyczną profesjonalną działalnością. 


\section{Zakończenie}

W kontekście przeżywanego historycznego momentu staje się bezdyskusyjną i zasadniczo ważną koniecznością fundamentalne uświadomienie ważności paradygmatu kształcącego tak, aby zachować to, co cenne, co już stworzono oraz rozwijać to, co wymaga odnowienia i wprowadzenia radykalnych zmian.

Zagadnienie kształcenia, tak jak to opisano powyżej, rzeczywiście jest ważne. W konsekwencji od jego rozwiązania głównie zależą perspektywy jego dalszego innowacyjnego rozwoju.

Wykładowca, jak o tym świadczy obszerne doświadczenie dydaktyczne wielu dydaktyków pracujących w dziedzinie kreatywnego paradygmatu, występuje jako kierownik nauczania kreatywnego; aktywizuje i stymuluje twórcze i poznawcze motywacje studentów; przedstawia nauczanym materiał o kreatywnym i innowacyjnym charakterze.

Rozwiązanie zadań twórczego rozwoju osobowości może być bardziej efektywnie realizowane, gdy studenci włączają się do specjalnie zorganizowanej twórczej działalności, która stymuluje ich intelektualnie i zwiększa pewność siebie, kształci określoną niezależność w wyrażaniu poglądów, a także zabezpiecza motywacyjnotwórczą aktywność, która pozwala osiągnąć określone cele przy rozwiązywaniu niestandardowych zadań w różnych rodzajach działalności i w różnych kontekstach.

\section{Bibliografia}

Ausubel, D.P., Novak, J.D. i H. Hanesian. 1968. Educational psychology. A cognitive view. New York: Holt, Rinehart and Winston.

Bartlett, F. 1985. Thinking: an experimental and social study. London: Allen and Unwin.

Bourne, L., Ekstrand, B. i R. Dominowski. 1985. The psychology of thinking. Englewood Cliffs. NJ: Prentice Hall.

Brookfield, S. 1987. Developing critical thinkers: challenging adults to explore alternative ways of thinking and acting. San Francisco: Jossey-Bass Publishers.

Byrge, C. i S. Hansen. 2008. The creative platform: a didactic for sharing and using knowledge in interdisciplinary and intercultural groups. SEFI2008 Conference Proceedings. Holland: SEFI.

Treffinger, D.J., Isaksen, S.G. i K.B. Dorval. 2005. Creative problem solving: an introduction. Waco, TX: Prufrock Press.

Dakowska, M. 2007. Teaching English as a foreign language. Warszawa: Wydawnictwo Naukowe PWN.

Dakowska, M. 2008. Psycholingwistyczne podstawy dydaktyki języków obcych. Warszawa: Wydawnictwo Naukowe PWN.

Dewey, J. 1963. How we think. Boston: Heath.

Faccione, P. 1998. Critical thinking: what it is and why it counts. LA Cruz, CA: California Academic Press.

Glatthorn, J. i J. Baron. 1985. „A good thinker”. W zbiorze: Costa, A. (red.). Developing minds. Alexandria, VA: Association for Supervision and Curriculum Development. 
Grucza, F. (red.) 1981. Glottodydaktyka a lingwistyka. Warszawa: Wydawnictwa Uniwersytetu Warszawskiego.

Hank, K. i J. Parry. 1991. Wake up your creative genius. Menlo Park, CA: Crisp Publications.

Krashen, S.D. 1982. Principles and practice in second language acquisition. New York: Prentice Hall.

McCrum, R., Cran, W. i R. MacNeil. 1986. The story of English. New York, N.Y: Elisabeth Sifton.

Nickerson, R., Perkins, D. i E. Smith. 1985. The teaching of thinking. Hillsdale, NJ: Lawrence Erlbaum Associates.

Nizhneva-Ksenofontava, N. 2009. Aspekt lingwistyczny doskonalenia kultury językowej studentów z wykorzystaniem zadań kreatywnych. Rozprawa doktorska. Białystok: Uniwersytet w Białymstoku.

Simensen, A.M. 1998. Teaching a foreign language. Principles and procedures. Bergen: Fagbokforlaget.

Taylor, C.W. 1988. „Various approaches to and definitions of creativity”. W zbiorze: Sternberg, R. i T. Tardif (red.). The nature of creativity. Cambridge: Cambridge University Press.

Torrance, E.P. 1974. Torrance tests of creative thinking. Benzenville, IL: Scholastic Testing Service Inc.

Torrance, E.P. 1966. Guiding creative talent. Englewood Cliffs, N.J: Prentice-Hall.

Zaniewski, J., Nizhneva, N. i N. Nizhneva-Ksenafontava. 2015. „Kreatywność w glottodydaktyce”. W zbiorze: Puppel, S. (red.). MOTEK. Motywy ekolinwistyczne: $w$ stronę ekoglottodydaktyki. Poznan: Katedra Ekokomunikacji UAM. 219-226.

Афанасьев, В.В. 2003. Педагогические технологии управления учебно-познавательной деятельностью студентов в высшей профессиональной школе: Дис. ... д-ра пед. наук. М.

Балобанова, Т.Н. 2005. Развитие творческой активности личности будущего специалиста [монография]; Курс. ин-т гос. и муницип. службы. Курск: Изд-во КИГМС.

Бим, И.Л. 2009. „Что означает личностная ориентация образования применительно к деятельности учителя”. Иностр. языки в школе 3. 2-9.

Гальскова, Н.Д. 2009. „Новые технологии обучения в контексте современной концепции образования в области иностранных языков". Иностр. языки в школе 7. 9-15.

Денисенко, П.А. 2009. Парадигмы образования в социокультурном пространстве современного российского общества. Москва: ВУ.

Игнатова, О.А. 2004. Становление творческой личности учителя в условиях школы нового типа : автореф. дис. канд. пед. наук. Рязань: РГБ.

Ильин, Е.П. 2009. Психология творчества, креативности, одаренности. Санкт-Петербург: Питер.

Китаев-Смык, Л.А. 2007. „Факторы напряженности творческого процесса”. Вопросы психологии 3. 69-82.

Кузина, С. 2011. Мозг врет! Тайны мозга. Знаем мозг - управляем собой. Москва: АСТ, Астрель.

Лефрансуа, Г. 2005. Прикладная педагогическая психология. Санкт-Петербург: Прайм-ВРОЗНАК.

Нижнева, Н.Н. 2009. „Творческое развитие личности в ходе учебной деятельности”. Веснік Беларускага Дзяржаўнага Універсітэта 4.2. 111-114.

Нижнева, Н.Н., Нижнева-Ксенофонтова Н.Л. 2009. „Учебный процесс и творческое развитие личности". Материалы 6 международной научной конференции: Европа и современная Россия. Интегративная функция педагогической науки в едином образовательном пространстве, 19-20 августа 2009, Ремини, Италия: МАНПО. 206-209.

Нижнева-Ксенофонтова, Н.Л. 2007. Конструктор креативной личности. Минск: Республиканский институт высшей школы.

Полат, Е.С. і М.Ю. Бухаркина. 2008. Современные педагогические и информационные технологии в системе образования. Москва: Издательский центр „Академия”.

Полонский, В.М. 2004. Словарь по образованию и педагогике. Москьа: Высшая школа.

Роджерс, К. 1994. К теории творчества: Взгляд на психотерапию. Становление человека. Москва: Прогресс. 
Роу, А.Д. 2007. Креативное мышиение. Пер. с англ. В.А. Островский. Москва: НТ Пресс.

Солдатова, А.А. 2000. „Подготовка учителя к инновационной деятельности в условиях ориентации на творческое самовыражение”. Вестник Иркутского педуниверситета 1. 10-13.

Фром, Э. 1992. Душа человека. Москва: Политическая литература.

Холодная, М.А. 2002. Психология интеллекта. Парадоксы исследования. Санкт-Петербург: Питер.

Хуторской, А.В. 2005. Педагогическая инноватика: методология, теория, практика. Москва: Изд-во УНЦ ДО.

Шамова, Т.И., Третьяков, П.И. і Н.П Капустин. 2002. Управление образовательньми системами. Москва: Издательский центр „Академия”. 